УДК 373.2.016:81-028.31

DOI https://doi.org/10.32838/2709-3093/2021.3/18

Дем'яненко С.Д.

Університет Григорія Сковороди в Переяславі

\title{
СЛОВОСПОЛУЧЕННЯ В МОВЛЕННІ СТАРШИХ ДОШКІЛЬНИКІВ
}

Статтю присвячено одній з актуальних проблем мовно-мовленнєвого розвитку дітей старшого дошкільного віку - оволодінню словосполученням як важливим мовним засобом та мовленнєвою одиницею. 3'ясовується, щзо вживання дітьми старшого дошкільного віку в мовленні різних видів словосполучень є показником розвитку мислення та початкових умінь співвідносити смисл сказаного з явищами мовленнєвої дійсності. Словосполучення у реченнях та висловлюваннях розгортає $і$ зміинює силу підібраних слів, сприяє закріпленню правил граматичної правильності мовлення, стає спробою дитини перейти до побудови складного поширеного речення. Відбирання дітьми мовних засобів для побудови речень та висловлювань стає можливим за умови, якщзо в арсеналі їхніх мовленнєвих навичок та умінь нагромаджена достатня кількість істотних характеристик (ознак) мовних одинииь. Актом комунікації дошкільнику притаманно передавати смисл, підбираючи адекватні мовні засоби. На шляху побудови висловлювання, передачі смислу діти часто потерпають від обмеженого запасу влучної лексики, а також відсутності уявлень про мовні одиниці. Тому з поміж мовних одиниць найважчим для засвоєння дітьми стає словосполучення як синтаксична одиниця мовлення. Закріплення істотних ознак словосполучення на мовлено-мовленнєвому рівні полегшує орієнтування дитини в мовленнєвій дійсності, сприяє більш швидкому підбору слів (назв, ознак, дій).

Розкрито поняття «словосполучення», виділено його істотні ознаки, лінгвістичні та психолінгвістичні підходи, особливості засвоєння дітьми старшого дошкільного віку.

Аналізуються результати проведеного дослідження вживання у мовленні словосполучень дітьми старшого дошкільного віку: на позначення сприйняття оточуючого світу (смакові, дотикові, зорові відчуття), засвоєння дітьми просторових та часових ознак, уявлення про світ предметний і процесуальний, які свідчать про наочно-практичне засвоєння дійсності й визначає наявність у мовленні дітей частин мови, представлених у різному співвідношенні. Наголошується на розробці технологій пропедевтики словосполучення у мовно-мовленнєвому розвитку дітей стариого дошкільного віку.

Ключові слова: словосполучення, висловлювання, мовлення, метамова, діти старшого дошкільного віку.

Постановка проблеми. У сучасному світі, пронизаному інформаційними технологіями, нагальним завданням стає розвиток мовлення та навчання мови підростаючого покоління. Інтенсивний мовленнєвий розвиток дітей старшого дошкільного віку дозволяє у буденному спілкуванні вживати всі одиниці мовлення: слова, словосполучення, речення, висловлювання. У своєму взаємозв'язку вони є головними в побудові висловлюваних думок, почуттів, бажань, донесенні та обміну інформацією. Усне мовлення дошкільників розвивається в процесі активної комунікації на основі усвідомлення сутності та відмінних рис мовних явищ. Розвиток мовлення дітей тісно пов'язаний 3 оволодіння мовою, оскільки у процесі мовлення (роботи 3 мовним матеріалом) відбувається засвоєння мовних одиниць (лінгвістичних понять), що повністю залежить від індивідуальних мовних здібностей і когнітивної сфери дошкільників. Активний мовленнєвий розвиток підводить старших дошкільників до розкриття їхніх метамовних здібностей та формування метамовних умінь, які вкрай значущі для подальшої мовної освіти дітей. Важливою серед мовних одиниць, які засвоюють діти, є словосполучення, без нього неможливо побудувати речення та висловлювання.

Аналіз останніх досліджень і публікацій. Низка вчених у своїх дослідженнях синтаксичної будови мовлення, побудови речень, навчання дітей розповідання, лексичної роботи 3 дошкільниками торкалися проблеми словосполучень у мовленні дошкільників. Серед них науково-практичні доробки А. Богуш, М. Вашуленка, I. Карабаєвої, В. Федієнка та інших. Значний внесок у розробку методики навчання дітей утворювати 
словосполучення в початковій школі, визначення основних напрямів цієї роботи внесли О. Гвоздєв, М. Вашуленко, Т. Ладиженська, М Львов, Т. Рамзаєва, Г. Фомічова, Н. Бакеева, Р. Сабаткоєв та інші. На необхідності оволодіння дітьми дошкільного віку мовленнєвою одиницею «словосполученням» у своїх дослідженнях наголошує Л. Калмикова.

У чинних програмах закладів дошкільної освіти роботу зі словосполученням як мовно-мовленнєвою одиницею, яку, безумовно, мають засвоїти діти дошкільного віку, до останнього часу не було визначено належним чином. Відсутні програмові завдання і зміст із формування граматичної будови мовлення з погляду обсягу словосполучень та їхніх суттєвих ознак як мово-мовленнєвої одиниці, назву (термін) якої вихователь час від часу вживає на заняттях у своїх поясненнях мовного матеріалу дітям. Своєчасна кваліфікована методична допомога дітям в умінні орієнтуватися (рефлексувати та об'єктивувати) мовно-мовленнєву дійсність, на наш погляд, сприятиме засвоєнню лінгвістичного поняття (словосполучення) та його істотних ознак.

Постановка завдання. Мета дослідження уточнити сутність поняття «словосполучення» 3 погляду наукових підходів, дослідити словосполучення в мовленні старших дошкільників та проаналізувати отримані результати.

Виклад основного матеріалу. Словосполучення розглядається як синтаксична одиниця, утворена поєднанням двох і більше повнозначних слів, пов'язаних між собою за змістом і граматично. У словосполученні виділяють головне і залежне слова. Від головного слова до залежного ставиться питання, за допомогою якого встановлюється змістовий зв'язок (годувати (чим?) кашею). Граматичний зв'язок здійснюється за допомогою закінчення залежного слова або закінчення і прийменника.

За будовою словосполучення поділяються на прості та складні. Прості словосполучення складаються з одного головного і одного залежного слова, не поширені (сміливий вчинок). У складних словосполученнях головне слово поширене іншим словом (героїчний подвиг народу). Слова в складі словосполучень і речень вступають в певні граматичні зв'язки. Як відомо 3 мовознавства, існують три види словосполучень (за значенням головного слова): 1) дієслівні - головним словом виступає дієслово (читати швидко, плакати слізьми); 2) іменні - головне слово виражене іменником, прикметником, займенником, числівником (малюнок дитини, п'ять іграшок). 3) прислівникові - головним словом $є$ прислівник (дуже добре, пізно вночі) [8].

Словосполучення визначають як смисловограматичне об'єднання двох або більше повнозначних слів на основі підрядного синтаксичного зв'язку: весняний день, покосити траву, здібний до навчання [3, с. 167].

Важливим для дослідження є розуміння словосполучення як поєднання двох або більше повнозначних слів, але при цьому об'єднані у словосполучення слова «виражають єдину назву предмета, уявлення і виступають однією поширеною назвою. Наприклад: дозрілі хліба, слава герою, турбота про людей, розмовляти голосно [6, c. 191].

Словосполучення, як і слово, має номінативну функцію - називає предмет, явище, процес, але відрізняється від нього будовою, складається із двох і більше самостійних слів. До спільних рис слова і словосполучення можна віднести такі:

- не є комунікативними одиницями;

- обоє позбавлені предикативності;

- характеризуються номінативною функцією;

- система форм слова і словосполучення визначувана стрижневим словом;

- виступають будівельним матеріалом для речення.

Водночас між словосполученням і словом $\epsilon$ суттєва різниця: в них різна кількість смислових показників; словосполучення $є$ мінімальним контекстом для слова; в словосполученні активно виявляються граматичні категорії опорних слів; словосполучення будується тільки на основі підрядного зв'язку. Словосполучення виконує номінативну функцію, а речення - комунікативну; словосполучення входить у комунікативну систему тільки через речення; словосполученню властива інтонація називання, а реченню - повідомлення; словосполучення вміщує не менше двох повнозначних одиниць, речення може складатися і з одного слова, пор.: відповідь землякам, лист товариша і Зима. Пізно; в словосполученні один із членів підпорядковується іншому (субординативні відношення), в реченні вони координуються один щодо іншого: квіти в росі, щасливий час і пахне троянда; Пролунало довгоочікуване «ура»!; в реченні наявна предикативність; із усіх наявних форм синтаксичного зв'язку в реченні реалізуються всі, а в словосполученні - тільки підрядний прислівний зв'язок; не всі сполучення слів у реченні є словосполученнями [8]. 
Водночас словосполучення виступає одиницею мови і мовлення. 3 лінгвістичного погляду словосполучення - це синтаксична одиниця, що складається не менше ніж із двох структурносемантичних організованих компонентів - головного (стрижневого) і залежного, що опосередковано (через речення) бере участь в комунікації $\mathrm{i}$ $\epsilon$ мінімальним фрагментом зв'язного мовлення. (Е. Смолянінова).

3 психолінгвістичного погляду оволодіння словосполученням в онтогенезі дозволяє розширити і закріплювати синтагматичні зв'язки між словами (лінійні, контекстні, його сполучуваність). У синтагматиці здійснюється комбінаторика значень і смислу, словосполучення чи речення не дорівнює сумі значень слів (синтагматичні відношення) [4].

Психолігнвістичний аспект словосполучення розширює і закріплює валентність (силу) слів, сприяє засвоєнню і закріпленню правил граматичного ладу мови, $є$ умовою засвоєння все більш ускладненої структури речення, зокрема умовою переходу від простого непоширеного речення до поширеного. Закріплення дітьми словосполучень полегшує вибір слова, оскільки на основі синтагматичних зв'язків одне слово ніби за ланцюжком «витягує» інше слово [8].

У дослідженні було здійснено теоретичний аналіз і узагальнення наукових джерел за темою дослідження (аналіз, синтез, порівняння, систематизація, узагальнення науково-теоретичних i емпіричних даних); вивчення мовлення дітей шостого року життя, бесіди $з$ дітьми, аналіз дитячих висловлювань.

Спостерігаючи за мовленням дітей дошкільного віку, ми звернули увагу, що вони здатні визначати ознаки предметів і дій, називаючи іменники словами-назвами, дієслова - словами-діями, а прикметники - словами-ознаками. На нашу думку, саме ці лексеми свідчать про розширення i уточнення мовленнєвої картини світу в мовленнєвій свідомості дітей. В процесі аналізу мовлення 3'ясували, що прикметників діти використовують більше, ніж прислівників. Тому словосполучення із прикметниками переважають (червона троянда, гарна сукня, весела гра, велика лялька ma інші). Прислівникових словосполучень у мовленні дітей зафіксовано зовсім мало (дуже весело, рано вранці та інші). Такий факт можна пояснити закономірностями пізнання дитиною дійсності, оскільки уявлення дошкільників про предметний світ залишаються ширшими, ніж уявлення про світ процесуальний.
Аналізуючи дитяче мовлення, зафіксували, що наочно-практичне засвоєння дійсності визначає наявність у мовленні дітей прикметників, які позначають сприйняття оточуючого світу: смакові, дотикові, зорові відчуття. Для позначення смакових відчуттів діти намагаються здійснити їх диференціацію. Таким чином з'являються словосполучення, утворені поєднанням прикметника 3 іменником (смачна иукерочка, солоденьке печиво, кислий лимон, солона риба, гіркий переиь тощо).

Позначаючи дотикові відчуття, діти старшого дошкільного віку вже можуть вживати слова, які означають неприємні та приємні відчуття (колючий їжачок, мокре взуття, брудні руки, гаряча праска, гострий ніж; теплі рукавички, м'яка подушка, гладенький стіл та інші). У мовленні дітей зафіксовано найбільшу кількість словосполучень, утворених прикметниками з іменниками на позначення кольору (зелена трава, червоний помідор, жовта диня, сине небо та інші). Крім того, діти часто використовують словосполучення, які позначають зовнішні ознаки предмета (косматий собака, яскраве сонще, нарядна дівчинка, здоровенний кавун, сильний дощ та інші).

Проаналізувавши мовлення дітей, можемо сказати, що утворення словосполучень із відповідними прикметниками свідчить про розширене розуміння їхніх значень. Вживати прикметники у мовленні точно, підбирати влучно, за смислом діти починають тоді, коли у них з'являється розширене розуміння значення предмета, дитина уже усвідомлює зв'язок «слово - явище дійсності», яке воно означає, називає.

Відповідно утворене словосполучення виступає важливою одиницею мовлення й мислення, висловлювання дитини. Мова вдосконалюється через засвоєння (сприймання й розуміння) достатнього мовного матеріалу (слів, словосполучень, речень, структурно різних текстів: розповідей, описів, міркувань), відповідно, розвивається й говоріння [7, с. 55].

У мовленні дітей також зафіксовані прикметники, які означають дотикові відчуття. Їх незначна кількість і вони одноманітні (холодний дощ, теплий чай, гарячий чайник, мокрі черевики, колючий шарф, я голодна). На позначення розміру отримані неоднозначні відповіді дітей: «великий» може означати - старший, дорослий, значний за розміром, сильний, наприклад, велике (високе) дерево; великий (старший) хлопчик, великий (потужний) кран та інші.

Утворення та вживання словосполучень пов'язано із засвоєнням дітьми просторових 
та часових ознак. Крім прикметників великий, маленький, довгий, короткий, високий, низький, діти вже засвоюють лівий, правий, товстий, тонкий, важкий, легкий. Часові параметри: старий, молодий часто помилково використовуються дітьми (розглядає своє фото у 2 роки: «молоденька я»; бабусю називає «молода бабуся», прабабусю «старенька бабуся»; розглядає іграшки «старі іграшки, а є і молоді іграшки», називає нові. Як бачимо, словосполучення, як і слово, називає предмет, істоту, але відрізняється від нього будовою, оскільки складається із двох і більше самостійних слів. Крім того, словосполучення не $є$ комунікативною одиницею, йому не властива інтонація завершеності думки.

Аналіз досліджуваного мовлення дітей показав, що діти старшого дошкільного віку майже не вживають прикметників і не утворюють словосполучень на позначення емоцій, хоча і досить емоційно реагують на оточуючу дійсність. Рідко вживають прикметники і майже не утворюють словосполучень, які означають інтелектуальні якості та пов'язані з соціальними явищами суспільства.

Вживання дітьми словосполучень із прикметниками залежить від вчасності засвоєння значення самого прикметника (слова-назви). У цьому процесі лежить пізнання зв'язку предметів і їхніх ознак, сприймання дитиною того, що предмет i ознака $є$ нерозривними. Завдання дитини розчленувати таку єдність, відокремити ознаку від предмета, розмежувати прикметник та іменник. Відокремлення ознаки від предмета та називання його ознаки «словом-ознакою», а самого предмета - «словом-назвою», визначення слова-дії та ознаки дії. У цьому сенсі ознайомлення старших дошкільників зі словосполученням передбачає практичне засвоєння його номінативної властивості: воно називає предмети, дії, їх ознаки, але називає більш конкретно. Ця робота проводиться під час зіставлення словосполучень зі словом, на основі поширення якого вони отримані, наприклад: будинок - високий будинок, низький будинок, кам'яний будинок, міський будинок та інші. Діти аналітичним шляхом доходять висновку, що словосполучення утворюють слова, сумісні за змістом. Не можна, наприклад, сказати сумний стілець. Крім того, в процесі спостережень 3'ясовується, що поєднання одного називного слова 3 іншим службовим словосполучення не утворює. Так, іменники 3 прийменниками (коротким, допоміжним словом) - на галявині, $y$ вод $i-\epsilon$ граматичною формою окремих слів, які не $є$ словосполученням.
У старшому дошкільному віці антропоцентрична картина світу, в якій живе дитина, іiі сприйняття дійсності розширюються. Дитина починає пізнавати значимий для неї внутрішній світ. У мовленні з'являються прикметники і словосполучення, пов'язані з позначенням емоцій: веселий, злий, лагідний, добрий, засмучений, ображений. Словосполучення 3 прикметниками, що означають емоції, дитина частіше вживає в третій особі (сором'язлива Аня, смішний клоун, веселі діти та інші), ніж стосовно власного емоційного стану. Власні емоції діти передають за допомогою одиниць процесуальної семантики (я веселюся, сміюся, плачу, злюся та інші).

У мовленні дітей старшого дошкільного віку з'являється оціночна лексика. Оцінювання здійснюється за розумовими здібностями, на позначення інтелекту (розумний). Дошкільники використовують лексеми, які пов'язані з прагматичною оцінкою. Ось, наприклад, утворені дітьми словосполучення з прикметниками - ціккавий мультик, незручний стільчик, шкідливий для природи, теплий шарф, корисний для здоров'я, модний костюм. На позначення естетичної оцінки зафіксовано такі словосполучення: красиве плаття, святкова зала, нарядна дівчинка.

У цьому віці в мовленні дітей з'являсться велика кількість відносних і присвійних прикметників, що відображають зв'язок ознаки 3 предметом чи особою, наприклад, поліиейський автомобіль, водійське посвідчення, лікарський халат, иегляний будинок, риб'ячий жир, кошача шерсть, курячі яйщя.

Вивчаючи словосполучення у мовленні старших дошкільників, ми виявили здатність дітей ставити запитання від головного до залежного слова словосполучення. Наприклад, червоне щьо? (яблуко, помідор); яблуко яке? (червоне, жовте, смачне, кругле); пояснення значення словосполучення (за межами речення, висловлювання). Наприклад, пояснити, щзо означає вислів «чисте повітря»?; визначення словосполучення (виправлення помилок під час вживання в мовленні словосполучень); уведення словосполучення у речення (придумування речень із запропонованими словосполученнями); переважання типів словосполучень у мовленні старших дошкільників. Здатність дітей старшого дошкільного віку членувати розгорнуті тексти-висловлювання на речення, речення на слова, а слова на звуки дозволить формувати у них уміння утворювати зі слів словосполучення - найменші синтаксичні одиниці, мовний матеріал. 
Однак, як наголошувала Н. Прутнікова, під час засвоєння синтаксичного ладу української мови дошкільниками слід ураховувати, що оволодіння словосполученнями не $є$ самоціллю, тому в роботі над цією проблемою, на нашу думку, необхідно використовувати вправи, які сприяють формуванню мовних умінь і розвитку мовленнєвих навичок дітей, а також вправи на складання речень, побудови висловлювань.

Висновки. Отже, головним у роботі над словосполученням є не повідомлення дітям будь-яких додаткових граматичних відомостей, а особлива організація навчального матеріалу, яка передбачає встановлення природних взаємозв'язків між морфологією, синтаксисом і лексикою під час засвоєння розділів програми мовно-мовленнєвого розвитку в закладі дошкільної освіти. Засвоєння на практиці істотних ознак словоспо- лучень, які можуть виражати різні синтаксичні відносини, сприятиме розвитку мислення і мовлення старших дошкільників. Ознайомлювати дітей зі словосполученням - значить працювати над елементами думки; вчити дітей розумінню словосполучень різного виду, логічних відносин у їх конструюванні. Складені дітьми словосполучення повинні міцно увійти в їх мовлення $\mathrm{i}$ мову. Оволодіння словосполученнями у переддень вступу до школи має проходити у практичному плані в двох аспектах, по-перше, словосполучення необхідно розглядати в структурі речення, висловлювання як його складову частину; по-друге, словосполучення варто засвоювати як розширену назву предмета. Мовленнєві навички вживання синтаксичної одиниці «словосполучення» повинні стати подальшим активним засобом розвитку рідної мови.

\section{Список літератури:}

1. Богуш А.М. Дошкільна лінгводидактика : теорія і практика. Запоріжжя : Просвіта, 2002. 216 с.

2. Вашуленко М.С. Державний освітній стандарт з української мови (початкова ланка) Початкова школа. 1997. № 2. С. 2-5.

3. Єрмоленко С.Я. Українська мова. Короткий тлумачний словник лінгвістичних термінів. Київ : Либідь, 2001. 224.

4. Кочерган М.П. Загальне мовознавство. Літературне місто. http://litmisto.org.ua/?p=15154.

5. Лурия А. Р. Язык и сознание. Ростов-на-Дону : 1998. 418 с.

6. Пентилюк М.І. Концептуальні засади мовної освіти як засобу інтелектуального й духовного розвитку особистості. Херсон : 2002. 352 с.

7. Розвиток мовлення дітей старшого дошкільного віку : монографія. за заг. ред. Л.О. Калмикової. Київ : Вид-во «ПП Медвєдєв», 2007. 304 с.

8. Синтаксис української мови URL: https://digilib.phil.muni.cz/bitstream/handle/11222.digilib/128795/ Books_2010_2019_018-2013-1_5.pdf? sequence=1.

9. Унарова В.Я̆. Формирование метаязыковых умений у младших школьников-билингвов как лингводидактическая стратегия обучения трем язикам. Педагогика и просвещение. 2020. № 2. С. 30-40. URL: https://nbpublish.com/library_read_article.php?id=32447.

\section{Demyanenko S.D. PHRASES IN THE SPEECH OF OLDER PRESCHOOLERS}

The article is assigned to one of the topical problems of the language-speech development of children of the senior preschool age - to the collocation received as an important language tool and speech unit. It turns out that the use of children of older preschool age in speech of different types of phrases is an indicator of the development of thinking and initial skills to relate the meaning of what is said with the phenomena of speech reality. Phrases in sentences and expressions unfold and strengthen the power of selected words, helps to consolidate the rules of grammatical correctness of speech, becomes an attempt by the child to move to the construction of a complex common sentence.

The selection of children's language tools for the construction of sentences and expressions becomes possible if the arsenal of their speech skills and abilities has accumulated a sufficient number of essential characteristics (signs) of language units. In communication, it is typical for a preschooler to retell meaning by selecting adequate language tools. In the way of constructing utterances and transmitting meaning, children often do not have the necessary vocabulary and ideas about language units. The most difficult for children to learn is the phrase as a syntactic unit of speech. Consolidation by children of essential signs of a phrase at the language-speech level promotes orientation of the child in speech reality, helps faster selection of words (names, signs, actions), to form a phrase. The article reveals the concept of "phrase", highlights its essential features, describes the linguistic and psycholinguistic approaches to the definition, features of the assimilation of phrases by children of older preschool age.

The results of a study of the use of phrases in speech by older preschool children are analyzed. Phrases spoken by children during the perception of the world (taste, touch, visual sensations), children's 
assimilation of spatial and temporal features, ideas about the world of subject and procedural, which indicate the visual and practical assimilation of reality and determines the presence in children's speech parts of speech different ratio.

The development of technologies of propaedeutics of a phrase in language and speech development of children of senior preschool age

Key words: collocation, phrase, moving, language about language, children of senior preschool age. 